\title{
Persistence of Demersal Fish Assemblages Between Cape Hatteras and Nova Scotía, Northwest Atlantic
}

\author{
Wendy L. Gabriel \\ National Marine Fisheries Service \\ Northeast Fisheries Science Center \\ Woods Hole, Massachusetts 02543 USA
}

\begin{abstract}
Persistent spatial boundaries and species membership of groundfish assemblages between Cape Hatteras and Nova Scotia from 1967 to 1988 were described based on Northeast Fisheries Science Center autumn bottom trawl surveys. Responses of several of those assemblages to perturbation by fisheries were also described. Cluster analysis was used to identify site groups with similar species composition and species groups with similar spatial distributions for each year. Assemblage responses were tracked by subregion over time, based on mean and percentage of total-biomass-per-tow by species and indices of species diversity. Six major site groups were defined with cluster analysis in most years. Major differences in site group boundary patterns were observed between northern site groups (Scotian Shelf, Gulf of Maine, Georges Bank) and southern site groups (Northern MidAtlantic Bight, Southern Mid-Atlantic Bight and Deepwater). Northern site groups were characterized by sharp boundaries which persisted in the same area from year to year and corresponded to depth features. Boundaries of southern site groups shifted from year to year probably reflecting an increased influence of temperature-related oceanographic features.
\end{abstract}

Membership in major species groups was highly persistent in time. Assemblages concentrated in northern subregions exhibited strong persistence in terms of spatial distributions as well. Although species group affiliations have persisted over time, the response of species groups to fishery perturbation varied among groups. Assemblages concentrated in northern regions did not appear resilient under fishery perturbation in the Gulf of Maine and Georges Bank subregions. Although comparable data were unavailable to characterize fishery perturbation in the Mid-Atlantic Bight area, during the same period that abundance of northern species groups continued to decline or remained at low levels, some migratory or potentially temperature-responsive species groups appeared to have extended their distributions northward, increased abundance, or both. Because many of these species are piscivorous and relatively underexploited, the result may be the potential addition of trophic linkages among assemblage groups as predator-prey interactions. Reversibility of fishery effects on productivity of less resilient assemblages will depend on the strength of trophic linkages both within and between assemblage production units that previously may have been uncoupled or only loosely coupled.

\section{Introduction}

Concern that perturbations by fisheries may lead to irreversible changes in struture and dynamics of marine communities has increased in the last decade (Sherman and Alexander, 1986). Although not caused by exploitation alone, the simplification of the Great Lakes fishery production system serves as a qualitative example of apparent irreversibility of assemblage structure (e.g. as discussed by Tyler et al., 1982). Theoretical studies reviewed by Beddington (1984) indicate that for exploited systems, multiple stable states of community structure are possible and, therefore, changes in structure are unlikely to be reversible.
Groundfish assemblages between Cape Hatteras and the Gulf of Maine have been significantly perturbed by fishing in the past 30 years (Brown et al., 1976; Mayo et al., this volume). Immediately after World War II, only the USA fleet was engaged in the fishery. Non-USA distant water fleets arrived in the mid-1960s resulting in substantially increased effort. The standardized effort levels (effort standardization described in Mayo et al., this volume) for the demersal fishery in the Georges Bank - Southern New England region (NAFO Div. 5Z) peaked in 1965, followed by major declines by the mid-1970s (fig. 4, Mayo et al., this volume), as biomass was depleted and regulations became more 
restrictive. Although standardized effort subsequently increased, recent levels are only $60 \%$ of the 1963-74 average, and between 1975 and 1980, effort was at levels comparable to those of 1960 .

This pattern was not consistent with the Gulf of Maine area (NAFO Div. 5Y), where nominal effort by the USA vessels was relatively constant until the mid-1970s (ICNAF, 1955-77), with little effort attributable to non-USA fleets. The fleet then began to shift to larger vessels and nominal effort then tripled by the mid-1980s (Fig. 1). (Comparable data or analyses for the Mid-Atlantic region are unavailable as reported in Mayo et al., this volume).

Examinations of the response of fish assemblages between Cape Hatteras and the Gulf of Maine after fishery perturbations (and relaxations) have been limited to short phases immediately following periods of high exploitation by distant water fleets. Brown et al. (1976) documented a 55\% decline in total finfish abundance between 1961 and 1972, between Cape Hatteras and the Gulf of Maine. Overholtz and Tyler (1985) examined changes in demersal fish assemblages on Georges Bank between 1963 and 1978. They indicated that the assemblage biomass showed some signs of recovery in the late-1970s, which they attributed to several good year-classes and declining effort under the Magnusson Fishery Conservation and Management Act.

The objectives of this paper are: (1) to identify persistent spatial boundaries and species membership of groundfish assemblages over the continental shelf between Cape Hatteras and Nova Scotia between 1967 and 1988, and (2) to compare re-

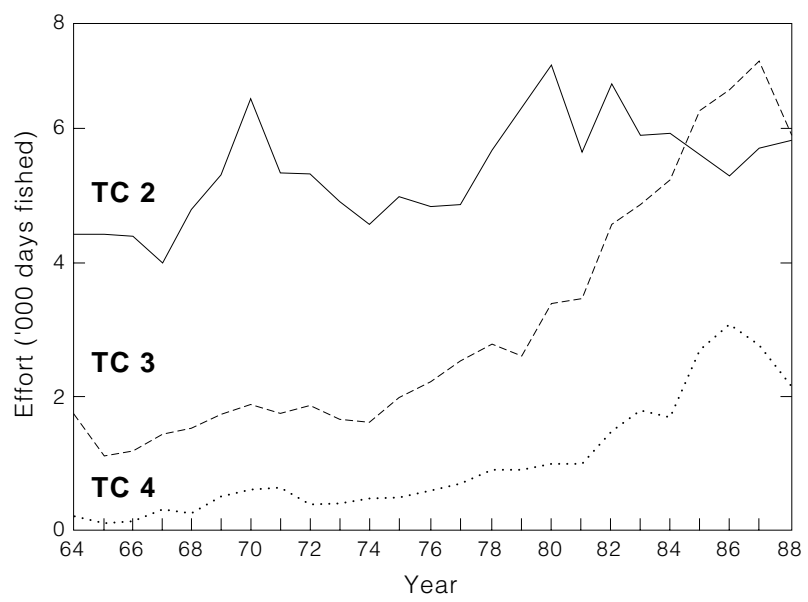

Fig. 1. Estimates of otter trawl effort in the Gulf of Maine (NAFO Div. 5Y, 1964-88 by vessel tonnage class (NEFSC weighout database): TC $2=5-50$ gross tons; TC $3=51-150$ gross tons; TC $4=151-500$ gross tons. sponses of several of those assemblages in the face of perturbation as a result of fisheries in terms of changes in total biomass, species composition and diversity.

\section{Environmental features of the study area}

The area extends from the continental shelf of western Nova Scotia to Cape Hatteras, at depths between $27 \mathrm{~m}$ and approximately $375 \mathrm{~m}$ (Fig. 2). The northernmost segment includes a topographically rugged set of hard substrate, deepwater basins and ledges in the central section of the Gulf of Maine, ringed on the northeast by a portion of the Scotian Shelf, on the northwest by the inshore Gulf of Maine shelf, on the southwest by Nantucket Shoals and on the south and southeast by Georges Bank. The Scotian Shelf and Georges Bank are separated by the Northeast Channel, which enters the Gulf of Maine. Georges Bank, a large, shallow submerged sandy moraine, is separated from Nantucket Shoals and the Mid-Atlantic Bight by Great South Channel. Southward, the shelf expands into the relatively wider, sand-bottomed Mid-Atlantic Bight.

Circulation in the Gulf of Maine is characterized by a relatively slow closed counterclockwise gyre which receives water at depth through the Northeast Channel. The water flows outward over Nantucket Shoals toward the Mid-Atlantic Bight. On Georges Bank, four physical regimes influenced by semidiurnal tides have been described (Butman and Beardsley, 1987): a northern flank, the bank crest, the southern flank which extends southwestward toward the southern New England region, and the deeper segment of the southern flank which does not recirculate around the bank. A well-developed clockwise gyre occurs on Georges Bank in the spring, but breaks down in summer and autumn. A general southwest shoreline flow continues along the Mid-Atlantic Bight. A cold pool of bottom water forms over the shelf south of Cape Cod, as a seasonal thermocline forms in the spring. The pool dissipates from north to south with the autumn overturn. In summer, a belt of warm offshore water extends eastward along the shelf edge along Georges Bank, between the 90-120 and 200-250 m contours (Cook, 1988).

During the study period, shelf water temperatures fluctuated from relatively cold in the mid1960 s to warm in the early to mid-1970s (Holzwarth and Mountain, MS 1990). Intermediate temperatures were observed between 1978 and 1982, with warmer temperatures occurring between 1983 and 1986 and cooler than average temperatures between 1987 and 1989. Interannual variation in temperature was larger in the Middle Atlantic Bight region (range of $3^{\circ}$ to $4^{\circ} \mathrm{C}$ ) than in the Gulf of Maine 


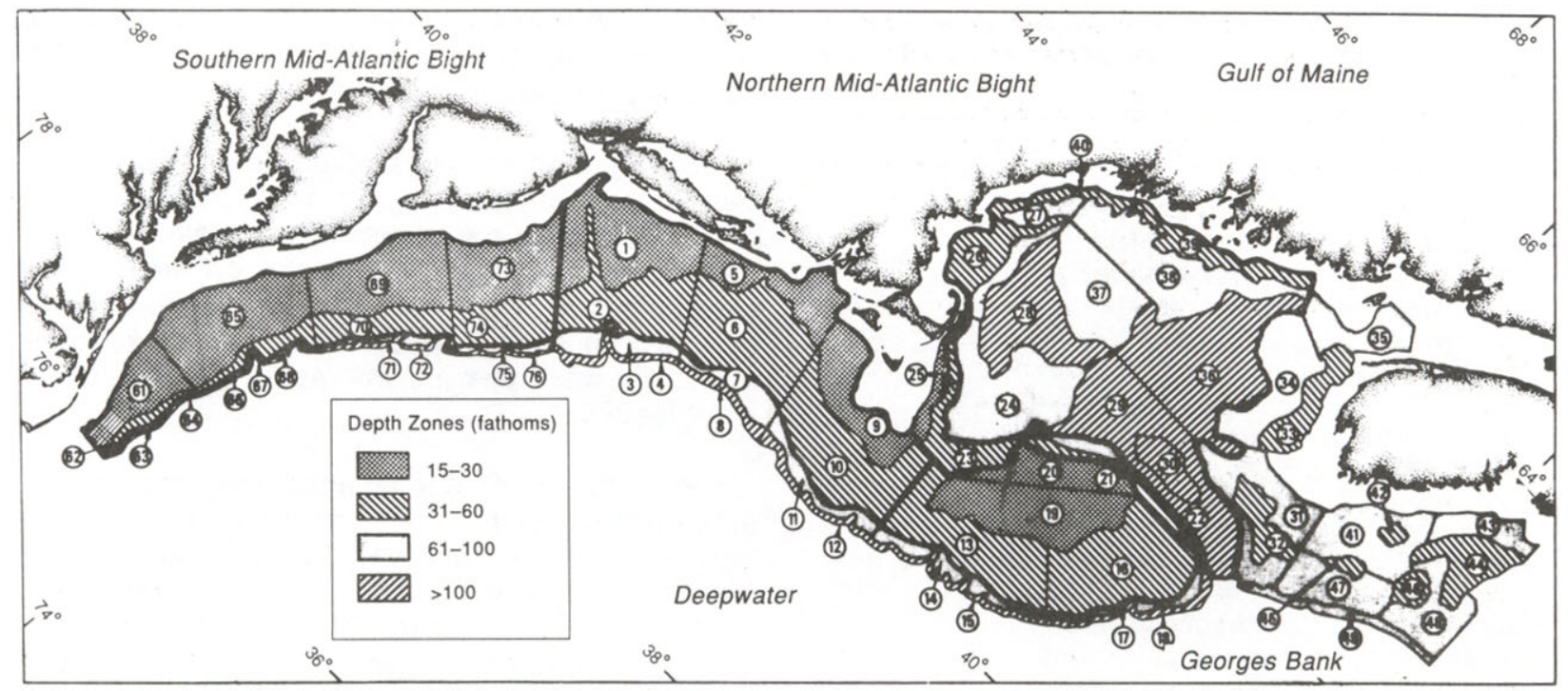

Fig. 2. Survey area map of the Northeast Fisheries Science Center showing offshore (depths $>27 \mathrm{~m}$ ) bottom trawl sampling strata extending between Cape Hatteras to Nova Scotia. Strata sets used in subregion summaries are outlined.

or on Georges Bank ( $2^{\circ}$ to $\left.3^{\circ} \mathrm{C}\right)$ (Holzwarth and Mountain, MS 1990).

\section{Materials and Methods}

The Northeast Fisheries Science Center has conducted autumn trawl surveys of the Northwest Atlantic continental shelf off USA annually since 1963 (Grosslein, 1969). The surveys extended from the Scotian Shelf to the Mid-Atlantic Bight, and south to Cape Hatteras (Fig. 2) after 1967 (Azarovitz, 1981). Details of survey methodology are described by Grosslein (1969) and Azarovitz (1981).

Data from these autumn surveys were used because a single trawl type was used throughout the series. All offshore $(>27 \mathrm{~m})$ strata north of Cape Hatteras were included in each year's analysis. Trawl tows with unsatisfactory gear conditions or tow durations were eliminated in the 1982-88 period of the series; the effect of this elimination was small because only a small percentage of approximately 300 stations/survey total tows fell into this category. Thus, all tows were included from the 1967-81 period. No adjustments in catch data were made for differences in catchability among species. Fiftyfour species were included in the analysis, consisting of commercial species, non-commercial but potentially dominant species on a regional basis, and potential forage species (Table 1). All species were present in at least $1 \%$ of the total observed tows with the exception of six species which exceeded the $1 \%$ criterion at the beginning of the period but declined thereafter (lumpfish, northern puffer, round scad) or exceeded the $1 \%$ criterion for an interval within the time series (croaker, weakfish, spot).

Hierarchical agglomerative cluster analysis (Clifford and Stephenson, 1975) was used to produce a series of site groups with similar species compositions for each year from 1967 to 1988. Observations at each site consisted of $\log _{10}$ transformed biomass-per-tow of each of 54 species. Bray-Curtis dissimilarity coefficients were calculated for each pair of sites. Clustering was based on group average fusion strategy, and a dendrogram was produced for each analysis showing at what dissimilarity levels the sites and groups were fused. Species composition of sites in a group forming at a low level of dissimilarity was more homogeneous among sites than species composition of sites in a group forming at a higher level of dissimilarity. Site groups were mapped as boundaries drawn around sites that belonged to clumps found in a dendrogram site cluster. Site group boundaries included sites in cluster groups which were contiguous on a map, where contiguous location may indicate ecologically homogeneous areas suitable for multispecies management approaches (Tyler et al., 1982). Although one map was produced for each year, maps (and dendrograms) from only three selected years (1968, 1976, and 1987) are displayed herein as examples of temporal variability and trends in site group boundary location over the sampled time series. For those examples, site groups were labelled to reflect hierarchical structure of cluster groupings: each major site group (e.g. 1, 2 or 3) could include component subgroups (e.g. subgroups $1 \mathrm{~A}$ and $1 \mathrm{~B}$ within major site group 1 ; and 
TABLE 1. Species encountered in the survey included in the analysis. Common names are cited in the text.

\begin{tabular}{|c|c|}
\hline Common name & Scientific name \\
\hline Spiny dogfish & Squalus acanthias \\
\hline Winter skate & Raja ocellata \\
\hline Little skate & Raja erinacea \\
\hline Thorny skate & Raja radiata \\
\hline Round herring & Etrumeus teres \\
\hline Atlantic herring & Clupea harengus \\
\hline Alewife & Alosa pseudoharengus \\
\hline Blueback herring & Alosa aestivalis \\
\hline Offshore hake & Merluccius albidus \\
\hline Silver hake & Merluccius bilinearis \\
\hline Atlantic cod & Gadus morhua \\
\hline Haddock & Melanogrammus aeglefinus \\
\hline Pollock & Pollachius virens \\
\hline White hake & Urophycis tenuis \\
\hline Red hake & Urophycis chuss \\
\hline Spotted hake & Urophycis regia \\
\hline Longfin hake & Urophycis chesteri \\
\hline Fourbeard rockling & Enchelyopus cimbrius \\
\hline Cusk & Brosme brosme \\
\hline Atlantic halibut & Hippoglossus hippoglossus \\
\hline American plaice & Hippoglossoides platessoides \\
\hline Summer flounder & Paralichthys dentatus \\
\hline Fourspot flounder & Paralichthys oblongus \\
\hline Yellowtail flounder & Pleuronectes ferrugineus \\
\hline Winter flounder & Pleuronectes americanus \\
\hline Witch flounder & Glyptocephalus cynoglossus \\
\hline Windowpane & Scopthalmus aquosus \\
\hline Gulf Stream flounder & Citharichthys arctifrons \\
\hline Atlantic mackerel & Scomber scombrus \\
\hline Butterfish & Peprilus triacanthus \\
\hline Bluefish & Pomatomus saltatrix \\
\hline Atlantic croaker & Micropogonias undulatus \\
\hline Black sea bass & Centropristis striata \\
\hline Scup & Stenotomus chrysops \\
\hline Weakfish & Cynoscion regalis \\
\hline Spot & Leiostomus xanthurus \\
\hline Redfish & Sebastes fasciatus \\
\hline Blackbelly rosefish & Helicolinus dactylopterus \\
\hline Moustache sculpin & Triglops murrrayi \\
\hline Longhorn sculpin & $\begin{array}{l}\text { Myoxocephalus } \\
\quad \text { octodecemspinosis }\end{array}$ \\
\hline Sea raven & Hemitripterus americanus \\
\hline Lumpfish & Cyclopterus Iumpus \\
\hline Northern sea robin & Prionotus carolinus \\
\hline Armored sea robin & Perestedion miniatum \\
\hline Cunner & Tautogolabrus adspersus \\
\hline American sand lance & Ammodytes americanus \\
\hline Atlantic wolffish & Anarhichas lupus \\
\hline Ocean pout & Marcozoarces americanus \\
\hline Fawn cusk-eel & Lepophidium profundorum \\
\hline Northern puffer & Sphoeroides maculatus \\
\hline Goosefish & Lophius americanus \\
\hline Round scad & Decapterus punctatus \\
\hline Short-finned squid & Illex illecebrosus \\
\hline Long-finned squid & Loligo pealei \\
\hline
\end{tabular}

clusters $1 \mathrm{Ai}$ and $1 \mathrm{Aii}$ within subgroup $1 \mathrm{~A}$ ), with each level of labelling (and line pattern in the maps) representing a lower level of dissimilarity among member sites at that level. A single generalized composite map of common features over the 196788 period was also produced.

Cluster analysis was also used to determine persistence of membership in species groups. Observations for each species consisted of $\log _{10}$ transformed biomass-per-tow at each site (inverse classification). A dendrogram indicating species groups with similar spatial distributions was produced for each year as well as for years 1967-88 combined.

Responses of assemblages were tracked by subregion over time, based on mean and percentage of total biomass-per-tow by species and Simpson's index of diversity (Ludwig and Reynolds, 1988). Subregions were defined as survey strata sets (Fig. 2) approximating persistent site group boundaries: Gulf of Maine, strata 24, 26-30, 36-40; Georges Bank, strata 13, 16, 19-21 (excluding Transition Zone strata 23, 25); Northern Mid-Atlantic Bight, strata 1-2, 5-6, 9-10; Southern Mid-Atlantic Bight, strata 61-62, 65-66, 69-70, 73-74; and Deepwater, 3-4, 7-8, 11-12, 14-15, 17-18, 63-64, 67-68, 71-72 and 75-76.

\section{Results \\ Persistent spatial boundaries}

When maps of site groups were compared among years, the single strongest, most persistent feature was a site group boundary separating Georges Bank from the Gulf of Maine, which closely followed the $100 \mathrm{~m}$ depth contour (Fig. 3). That boundary was observed each year, and separated site groups at dissimilarity levels of 0.7-0.9.

Sites north of the Georges Bank boundary regularly grouped into a Gulf of Maine region and an affiliated Scotian Shelf region. A boundary between those two regions appeared in 18 of 22 years, close to the $100 \mathrm{~m}$ contour of the Scotian Shelf and extending south across the Northeast Channel. Scotian Shelf site groups tended to form at slightly higher levels of dissimilarity than Gulf of Maine site groups. The boundary between Georges Bank and more northern sites occasionally appeared as a narrow band of sites, again following the $100 \mathrm{~m}$ contour of the northern edge of Georges Bank. This 'Transition Zone' site group (area A, Fig. 3) appeared in 7 of the 22 analyses, with no temporal pattern, and was often affiliated with the Scotian Shelf site group, as the level of dissimilarity among Transition Zone sites was often higher than among deepwater Gulf of Maine sites. A small group of sites on the western inshore section of the Gulf of Maine (area B, Fig. 3, just north of Cape Cod) occasionally (5 of 22 years) appeared separately from the large deepwater group, as well. 


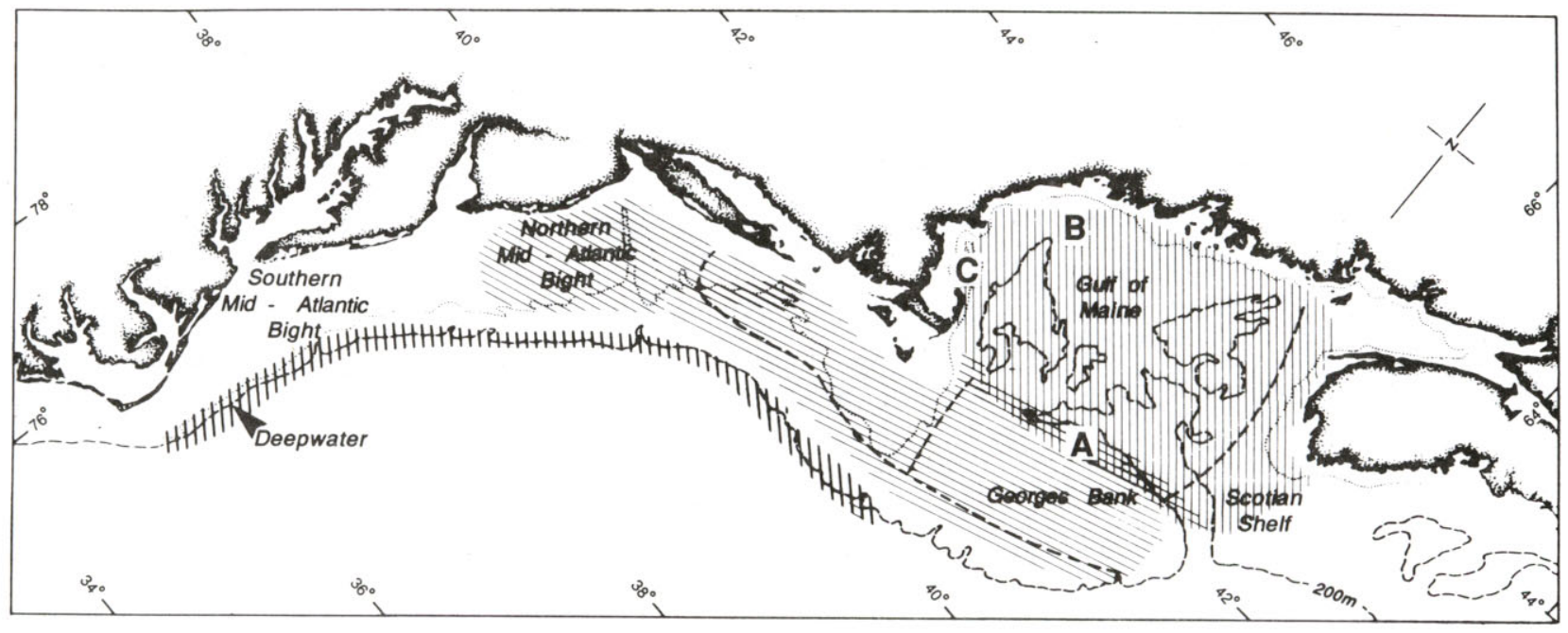

Fig. 3. Composite of assemblage maps based on cluster analysis of trawl survey data 1967-88. Boundaries may shift from year to year, as shown by dashed lines. Not all features are equally strong each year. Some features (A = Transition Zone; $\mathbf{B}=$ Inshore Gulf of Maine; $\mathbf{C}=$ Massachusetts Bay/Stellwagen Bank sites groups) appear occasionally.

Although a 'Deepwater' site group region formed at relatively high levels of dissimilarity (given the low number of sites usually included in the group), it appeared consistently as a narrow band of deepest sites (usually $>100 \mathrm{~m}$ ) extending from off the Virginia-North Carolina coast to the southern edge of Georges Bank. The eastward extent of the site group varied over time, initially reaching only as far as the Great South Channel, then extending further east in the early-1970s and reaching the entire southern edge of the Bank in the late-1970s. During the 1980s, the eastward extent varied from year to year. This site group generally joined with other major Mid-Atlantic Bight site groups, rather than affiliating with Georges Bank or Gulf of Maine/Scotian Shelf groups.

Major site group boundaries from south of Georges Bank varied more extensively from year to year. Core groups of sites could be located within Georges Bank in every year, however, the western extent of those site groups also varied from year to year. Between 1967 and 1972, sites from Georges Bank and the Northern Mid-Atlantic Bight were affiliated (occasionally as subgroups) in one large cluster. Spatially, sites in that cluster were distributed as far south as off the southern border of New Jersey (1967-69) (Fig. 4 and 5 show an example of 1968). The southern extent of the site group moved north and east during the early-1970s, until the 1974-79 period, when the site group (in 5 of the 6 years) extended only as far as the shelf off the middle of Long Island (Fig. 6 and 7 show an example of 1976). The picture in the 1980s was more variable from year to year, but one tendency in some years was the displacement of the Georges Bank - Northern Mid-Atlantic Bight boundary northward, especially along the southern edge of Georges Bank (Fig. 8 and 9 show an example of 1987).

Years of shrinkage of the area occupied by the Georges Bank - Northern Mid-Atlantic Bight site group was matched by a complementary expansion of a Southern Mid-Atlantic Bight site group. This site group was characterized by discontinuous spatial distributions of sites in clusters, i.e. sites adjacent to each other on the dendrogram may be widely separated in space or distributed as patches on a map. Sites were contiguous when large clusters were examined (at relatively aggregated levels of hierarchical clusters). Deepwater site groups were usually affiliated with these site groups.

\section{Persistent species groups}

Membership in species groups (species with similar distribution patterns) was highly consistent from year to year. Results of analysis of all years combined (Fig. 10) were generally similar to those obtained for each individual year (with exceptions noted below). Six groups typically occurred each year related to assemblage regions (where two regions were indicated, the distribution was concentrated in the first region): A. Deepwater Gulf of Maine- Georges Bank; including thorny skate, American plaice, white hake, redfish and witch flounder; B. Gulf of Maine-Georges Bank Transition Zone; species closely affiliated with Group A, including Atlantic cod, haddock and pollock; C. Shallow Water Georges Bank-Southern New England; typi- 


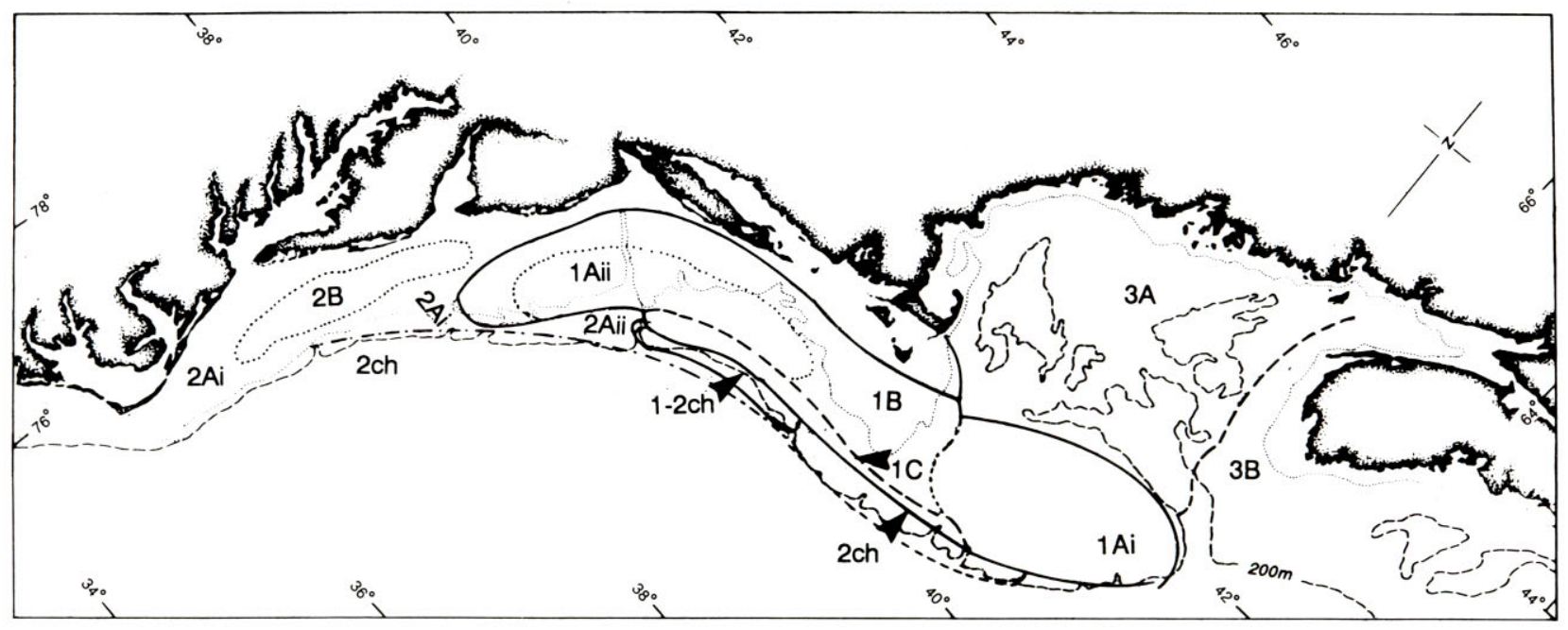

Fig. 4. Assemblage map based on cluster analysis of trawl survey data of 1968. Site group labels and boundaries correspond to dendrogram structure and dissimilarity levels in Fig. 5. Sites in areas $2 \mathrm{ch}$ (ch=chain) are only loosely affiliated with other sites in area 2.

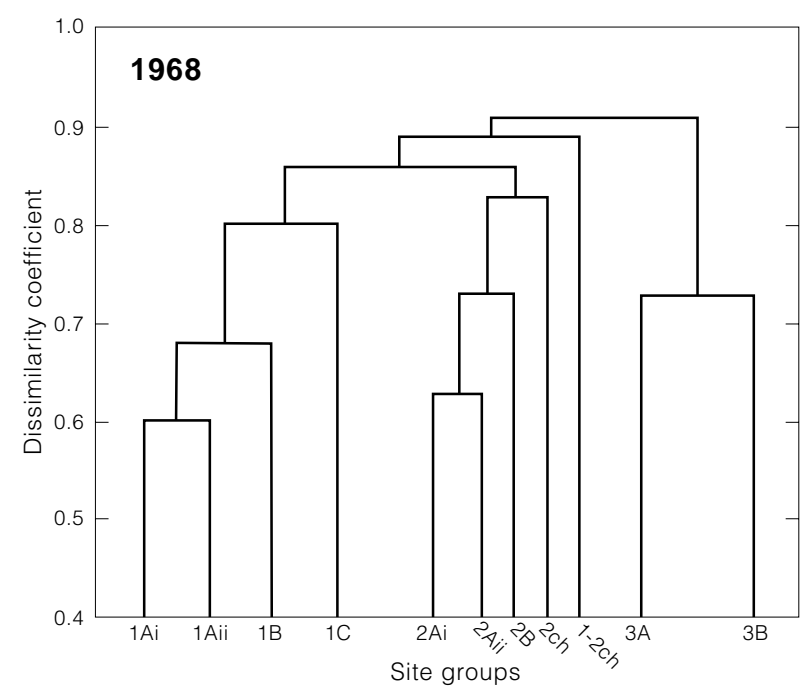

Fig. 5. Schematic dendrogram of site clusters from cluster analysis of trawl survey data of 1968. Ch refers to sites affiliated with major site groups (e.g. 2 ch with site group 2 and 1-2 ch with site groups 1-2 combined), but not included in specific subgroups by the analysis.

cally including winter skate, little skate, windowpane, winter flounder, yellowtail flounder and longhorn sculpin; D. Northern Mid-Atlantic Bight; including spotted hake, fourspot flounder, butterfish and long-finned squid; E. Southern Mid-Atlantic Bight; including summer flounder, scup, northern sea robin, black sea bass, with a separate inshore warm-water component consisting of Atlantic croaker, spot and weakfish; and F. Deepwater, including offshore hake, blackbelly rosefish, longfin hake, armored sea robin, Gulf Stream flounder and fawn cusk-eel.

Affiliation of some important species, grouped in Fig. 10 as A-B, shifted over time. In the late1960s, silver hake, red hake, and goosefish were often grouped with species from groups C-D, while short-finned squid co-occurred with the Deepwater species group F. Spiny dogfish was variously grouped with $\mathrm{B}, \mathrm{C}$ and $\mathrm{D}$, depending on the year analyzed. In the mid-1970s, however, all those species were more frequently grouped with $A$. The pattern generally persisted through the 1980s, with the exception of the affiliation of spiny dogfish with group C in most years between 1978 and 1983. In the mid- to late-1980s, dogfish again were affiliated with more northern groups A-B, with short-finned squid affiliated with groups C-D.

Several relatively rare species were not clearly affiliated with major groups on an annual basis. When observations from the entire time series were combined, however, those species were joined with major groups consistent with long-term individual distribution patterns (Almeida et al., MS 1984). Sea raven and ocean pout (minor group $\mathrm{M}-1$ ) occurred occasionally as members of group $\mathrm{C}$ and alewife, Atlantic mackerel and Atlantic herring (M-2) formed a pelagic group, affiliated with more northern groups A-D. Atlantic halibut, Atlantic wolffish and moustache sculpin (M-3) were affiliated with more northern species groups A-D, while the affiliation of cunner and American sand lance (M-4) was likely to be with group $\mathrm{E}$. Other rare species $(\mathrm{M}-5)$ affiliating with group $\mathrm{E}$ included round herring, blueback herring and fourbeard rockling. Lumpfish, northern 


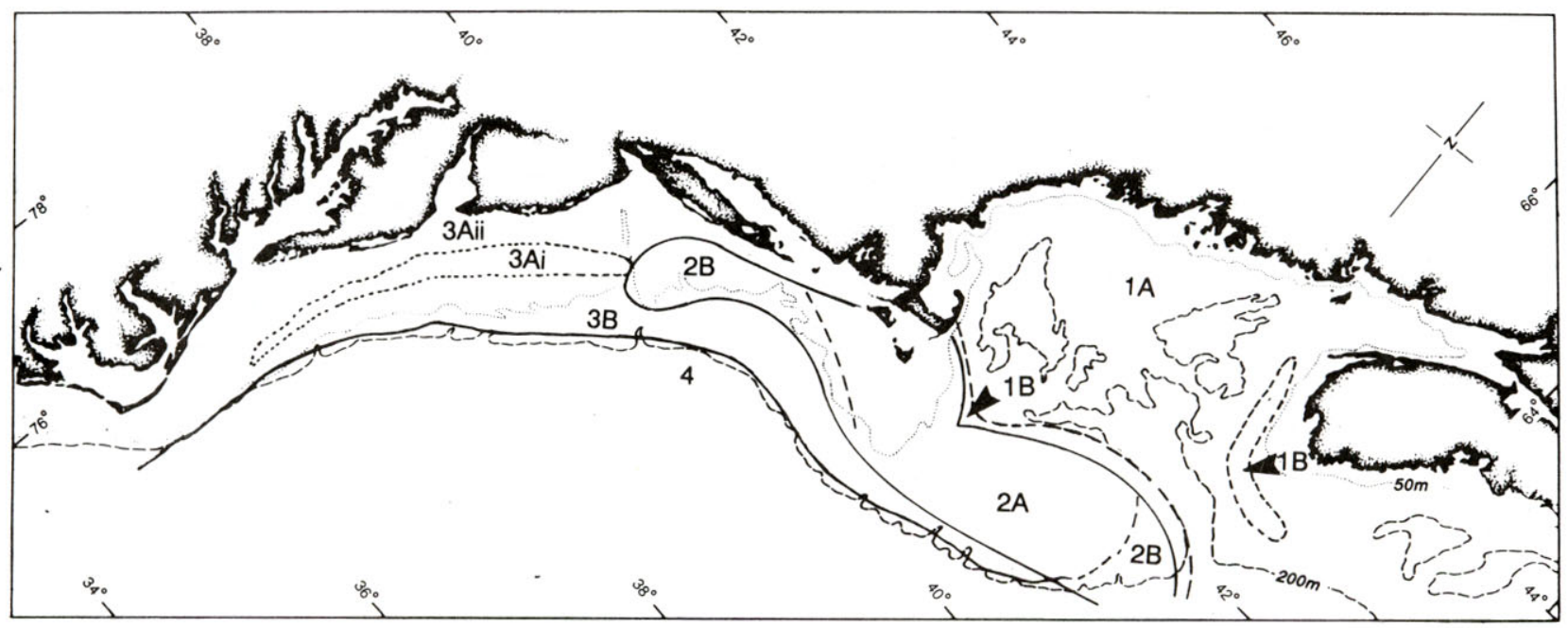

Fig. 6. Assemblage map based on cluster analysis of trawl survey data of 1976. Site group labels and boundaries correspond to dendrogram structure and dissimilarity levels in Fig. 7.

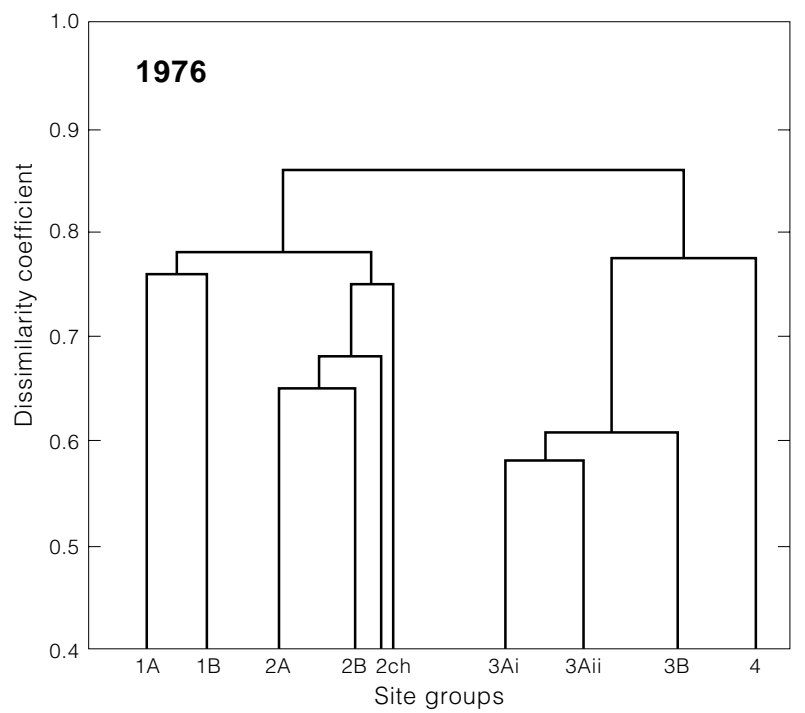

Fig. 7. Schematic dendrogram of site clusters from cluster analysis of trawl survey data of 1976. Ch refers to sites affiliated with major site groups (e.g. site group 2), but not included in specific subgroups.

puffer and round scad occurred so infrequently that they were not grouped with any previously defined groups.

The level of dissimilarity at which some cluster groups formed also changed over time. While group A generally formed at a lower level of dissimilarity (usually near 0.5 and less than 0.6) than groups associated with other regions, by the late-1980s, the primary species in the group (thorny skate, American plaice, witch flounder, redfish and white hake) were grouped together at higher levels of dissimilarity (0.6-0.7) and more chaining was observed in that cluster formation. Comparable changes were not observed in other groups, although species affiliations within those groups were initially at higher dissimilarity levels.

\section{Historical changes in assemblages by subre- gion}

Within the Gulf of Maine, the trend in aggregate biomass (as reflected by survey catch-per-tow, Fig. 11 and 12) can be qualitatively separated into three periods: initial decline (1963-74), resurgence (1975$81)$ and secondary decline (1982-88). This pattern appeared in three different species groups. The initial decline in abundance of species group A was pronounced for all species in the group except white hake (which showed a slight increasing trend initially), subsequent brief increases in the late1970s were observed for the two flatfish species and all species in the group declined in the most recent years. For group $B$, initial declines in abundance of haddock and Atlantic cod were substantial, and increases in the mid-1970s appeared with good year-classes of haddock and Atlantic cod and the presence of pollock, with recent declines observed for all three species. Survey biomass of group A-B species, primarily short-finned squid and goosefish, increased in the 1975-81 period. Until 1980 , the relative survey biomass of spiny dogfish declined. Along with spiny dogfish, red hake has been the major species to increase in survey biomass in recent years. The aggregate species composition shifted from a mixture dominated by redfish, haddock and Atlantic cod to a mixture dominated by spiny dogfish, white hake, silver hake and 


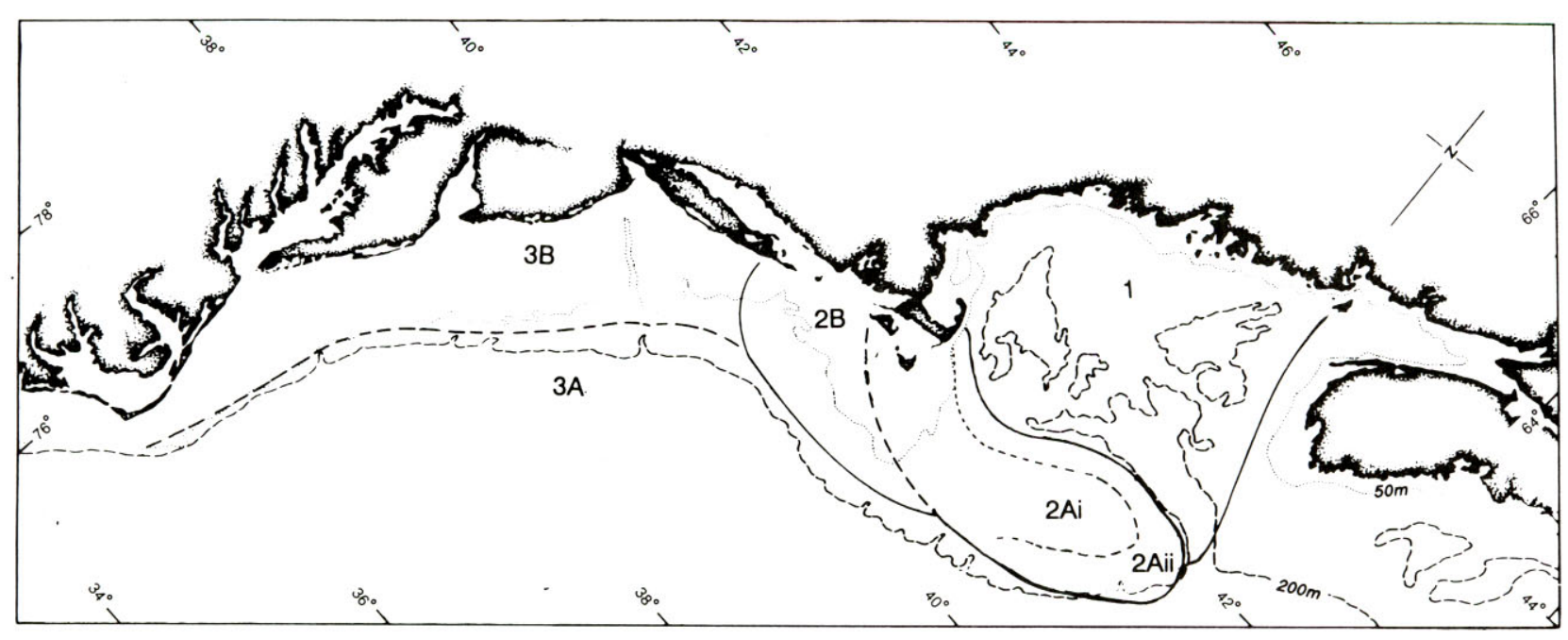

Fig. 8. Assemblage map based on cluster analysis of trawl survey data of 1987. Site group labels and boundaries correspond to dendrogram structure and dissimilarity levels in Fig. 9. Very few stations were occupied in the Scotian Shelf Region in 1987.

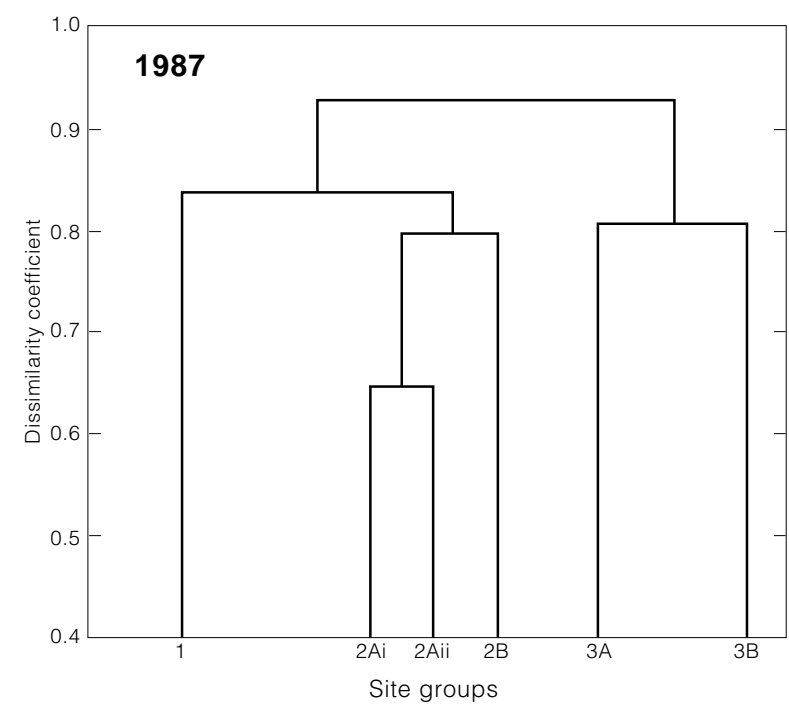

Fig. 9. Schematic dendrogram of site clusters from cluster analysis of trawl survey data of 1987.

Atlantic cod. Throughout these changes, diversity tended to increase slightly up until around 1976, due primarily to the reduction in biomass of redfish, a dominant species. Most recently, however, diversity may have declined.

Changes in biomass on Georges Bank have been documented (Mayo et al., this volume; Overholtz and Tyler, 1985). Similar to the Gulf of Maine, abundances of some groups of species declined until the mid-1970s, increased in the latter half of the 1970s with several good year-classes, and declined again to record low levels in the 1980s
(Fig. 12 and 13). This pattern was observed for species in group B and flatfish species in group $C$. Some species in group A-B showed declines in the 1960s (goosefish, red hake) while others appeared (intermittently) in the latter half of the 1970s. About half of the other species biomass was contributed by short-finned squid between 1976 and 1980. Although present in trawl survey catches at low levels in this region, the biomass of group $D$ species, especially butterfish and long-finned squid, more than tripled since 1967. Among elasmobranchs, spiny dogfish began to trend upward in abundance in 1973, while winter skate began to increase in 1977. The increase in biomass of these two species was responsible for the decline in diversity from peak levels in the late-1960s (after removal of haddock as a dominant species) to relatively low levels in the late-1980s.

In the Northern Mid-Atlantic Bight region, changes in aggregate biomass, species composition and diversity were influenced primarily by the relative abundance of spiny dogfish and species in groups C and D (Fig. 12 and 14). Between 1967 and 1988 , biomass shifted from group $C$ to group $D$, as the relative abundance of yellowtail flounder in the area declined between 1967 and 1974, and as abundance of butterfish, long-finned squid and fourspot flounder increased throughout the period. High relative abundance of spiny dogfish between 1963 and 1969 led to lower levels of diversity during that period. As relative abundance of spiny dogfish dropped in the early-1970s, diversity increased. Subsequent fluctuations in diversity were related primarily to fluctuations in dogfish abundance. On average, recent (1980-88) dogfish abundance has 


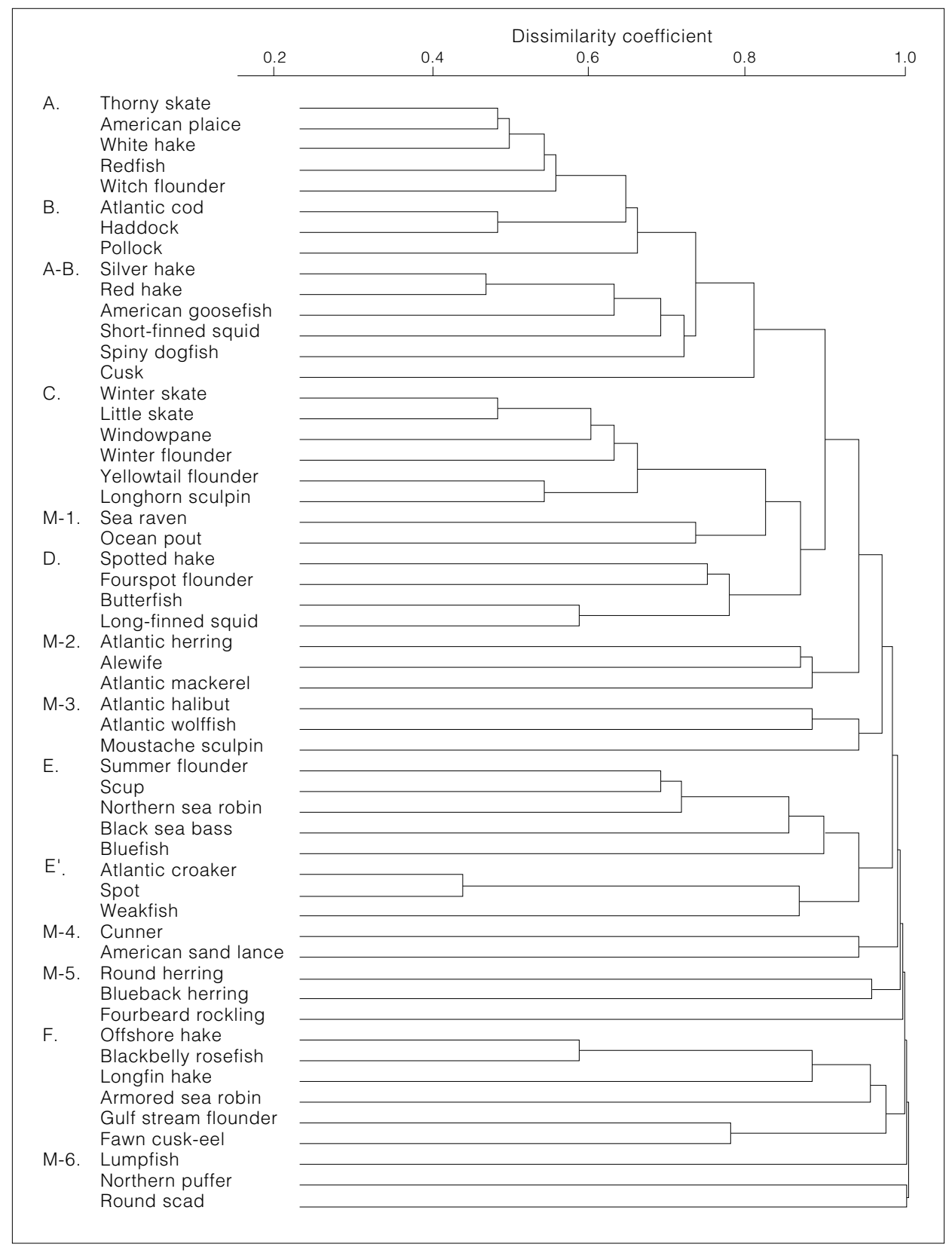

Fig. 10. Species groups and schematic dendrogram based on inverse cluster analysis of pooled 1967-88 groundfish survey data. Species groups $A=$ Deepwater Gulf of Maine-Georges Bank; B = Gulf of Maine-Georges Bank Transition Zone; C = Shallow Water Georges Bank-Southern New England; D = Northern Mid-Atlantic Bight; E = Southern Mid-Atlantic Bight; $E^{\prime}=$ Southern Mid-Atlantic Bight Occasional; F = Deepwater; $\mathrm{M1}$ 1-M6 = Minor species groups of rare or more loosely affiliated species. Second areas in group names represent secondary areas of concentration and/or second stock area for many species.

been lower than during the 1963-69 period. Species from group $E$ (e.g. summer flounder, scup) appeared at low levels of abundance in the region between 1972 and 1982. Among species in group $A-B$, abundance of goosefish declined since the early-1970s and especially since 1985; abundance of red hake and silver hake declined since 1984.
In the Southern Mid-Atlantic Bight region, patterns in aggregate biomass were characterized by intermittent spikes contributed by relatively few species (Fig. 12 and 15). Aggregate biomass showed a decline between 1967 and 1974, a peak during 1975-77, and a fluctuation around low to medium levels between 1978 and 1988. Diversity varied 

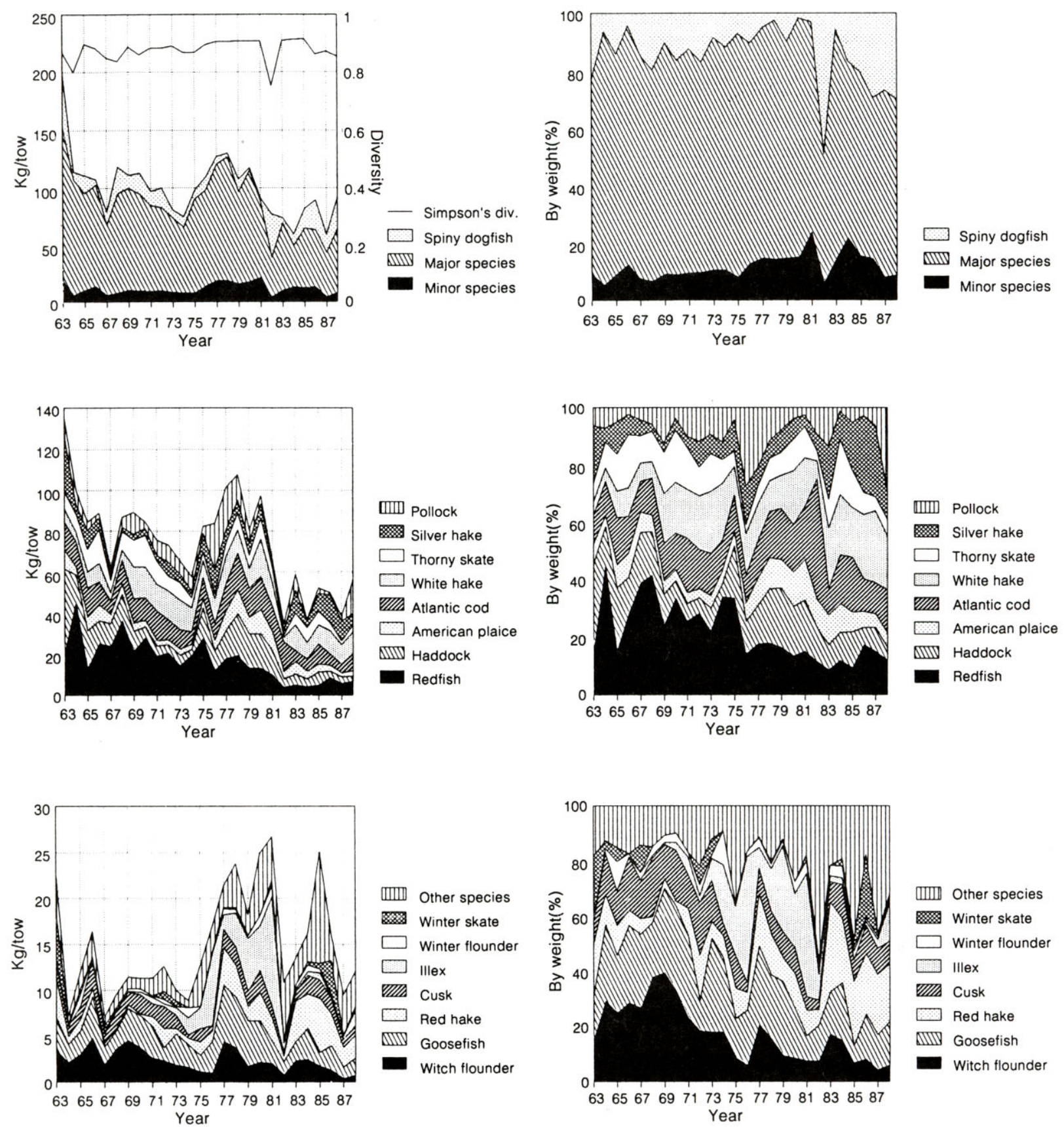

Fig. 11. Mean biomass (kg/tow), percent biomass and Simpson's diversity index, Gulf of Maine survey summary region (survey strata 24, 26-30, 36-40), 1963-88 based on 54 species (Table 1). Totals as mean $\mathrm{kg} / \mathrm{tow}$ (left panels) and percent total mean kg/tow (right panels) are aggregated over sets of major and minor species in top panels, and disaggregated by individual species in middle and lower panels.

widely throughout the series, influenced by the relative abundance of butterfish and long-finned squid, the dominant species within the region belonging to group D. Summer flounder, scup, spot and croaker (group E species) showed similar patterns of high relative abundance between 1975 and 1977 and again between 1983 and 1986 (especially in 1985).
In the Deepwater strata set, aggregate biomass showed a decline between 1967 and 1975, and increased between 1976 and 1981, and declined somewhat between 1982 and 1988 (Fig. 12 and 16). In the first period, most of the aggregate biomass was contributed by group D species, dominated by long-finned squid and butterfish. In the second period, increased abundance of short-finned squid 

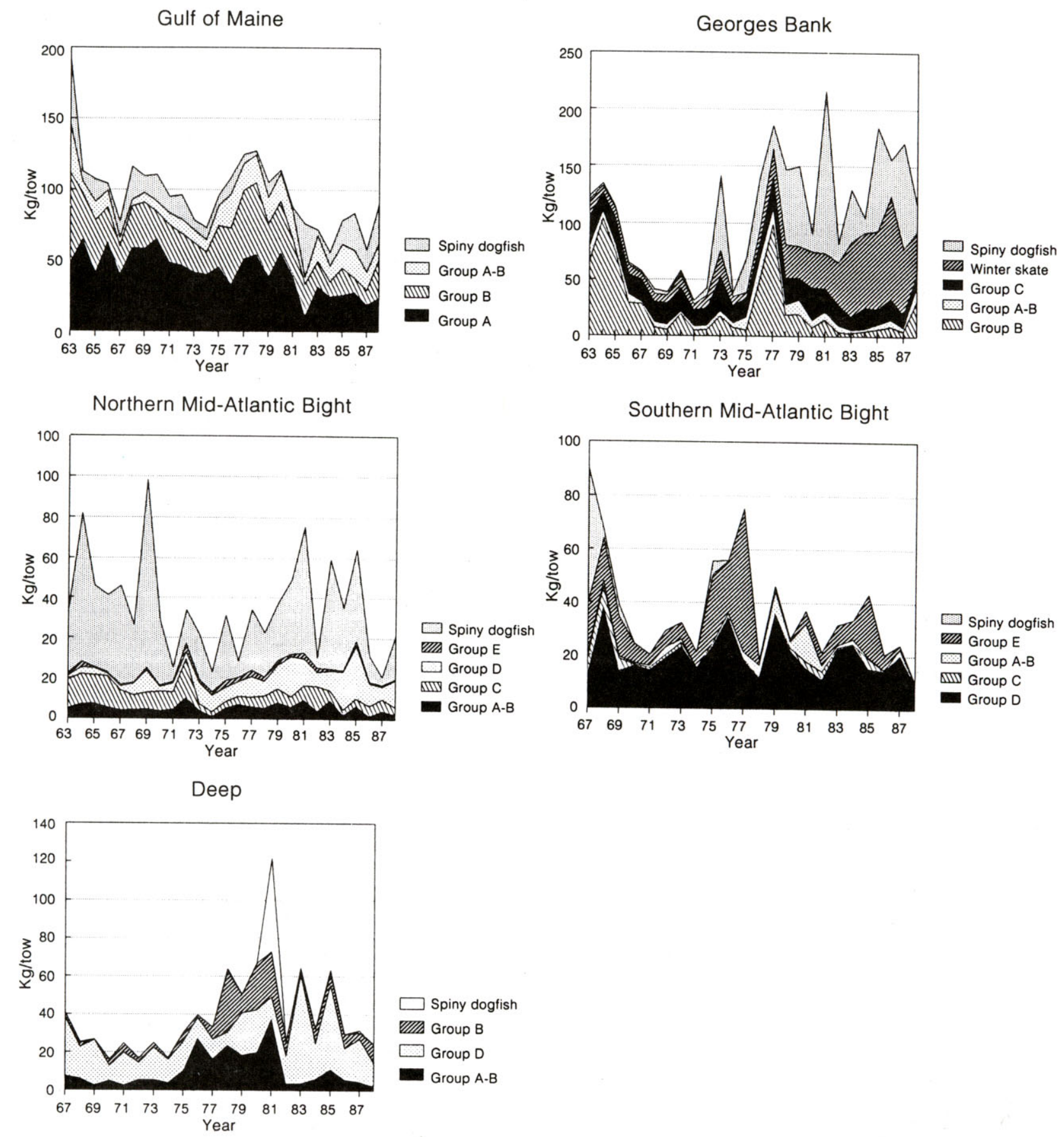

Fig. 12. Species composition by survey summary region and species groups from cluster analysis. (Catch-per-tow is aggregated over species within each group.) Spiny dogfish (group A-B) is outlined separately, as is winter skate (group C) for Georges Bank.

(1976-81), cod and haddock (1978-81) and pollock (1981) led to higher abundance levels in these strata. Most recently, biomass was dominated increasingly by butterfish, short-finned squid (group D) and Atlantic cod and haddock to a lesser extent (group B). Although diversity fluctuated fairly widely from year to year, there was no apparent trend.

\section{Discussion}

Persistence of spatial boundaries of assem-
blage regions

Distinct boundaries to assemblage site distributions between Cape Hatteras and Nova Scotia 


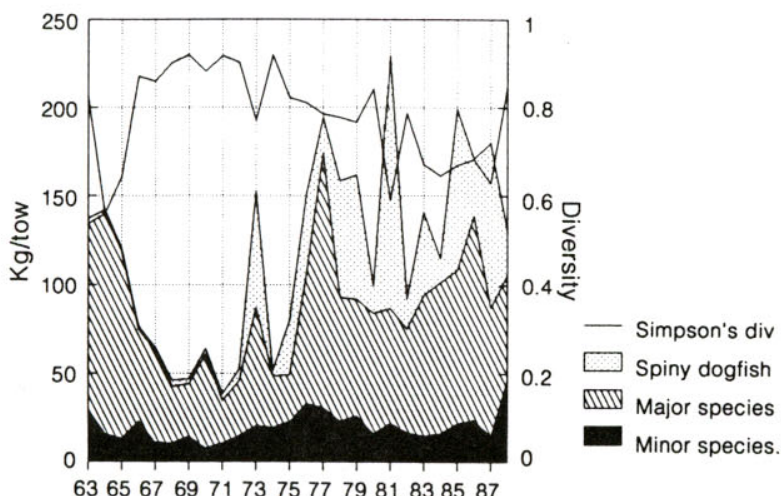

Year
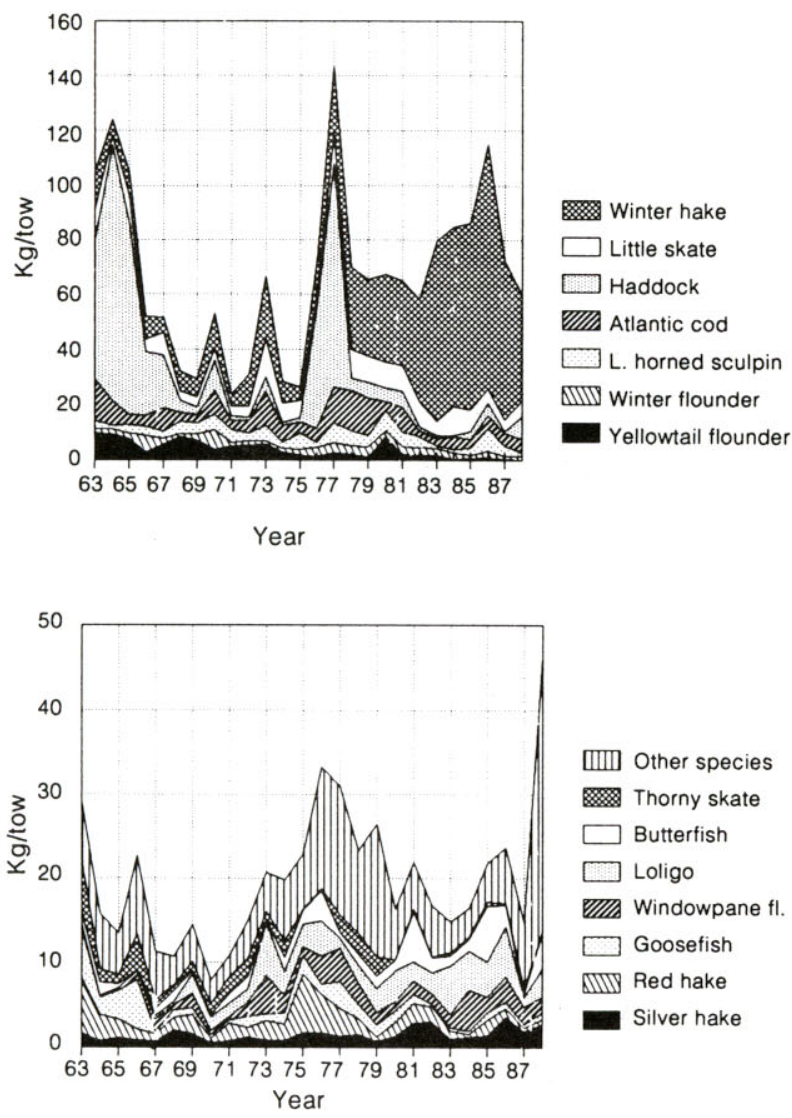
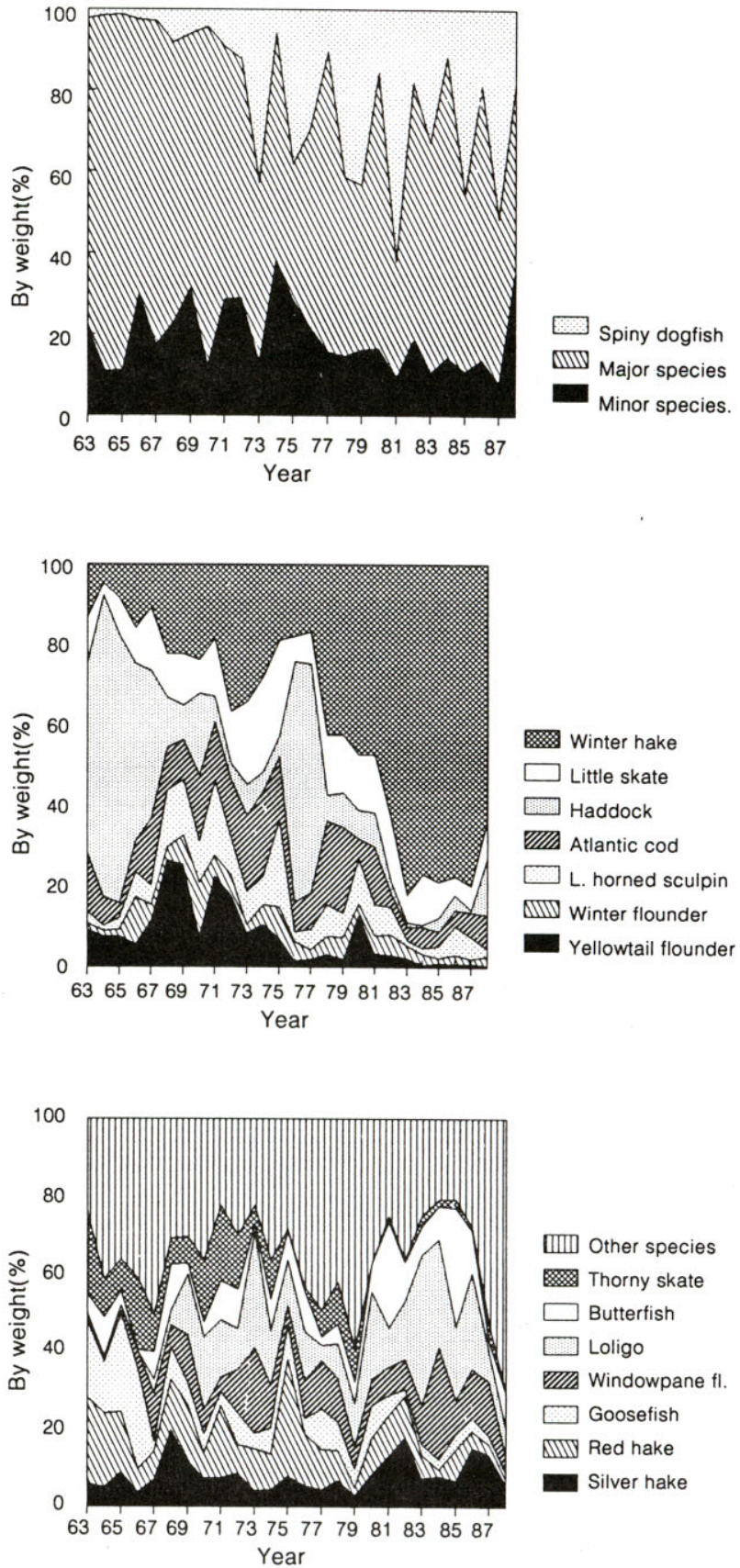

Fig. 13. Mean biomass (kg/tow), percent biomass and Simpson's diversity index, Georges Bank survey summary region (survey strata 13,16, 19-21), 1963-88 based on 54 species (Table 1). Totals as mean kg/tow (left panels) and percent total mean $\mathrm{kg} /$ tow (right panels) are aggregated over sets of major and minor species in top panels, and disaggregated by individual species in middle and bottom panels.

correspond to distinct regimes in the physical environment. The strongest, most consistently recurring cluster group boundary occurred between sites in the Gulf of Maine (and north) and sites on Georges Bank (and south), and corresponded to both a sharp change in depth and a change in hydrographic and circulation regimes (Cook, 1988). The Scotian Shelf region is separated from other Gulf of
Maine sites by depth. Within Georges Bank, assemblage region boundaries correspond very closely to physical regimes influenced by semidiurnal tides (Butman and Beardsley, 1987), which are a function of depth as well. In similar previous studies depth also has consistently been identified as a major environmental component in structuring demersal assemblage distributions (e.g. Day and Pearcy, 

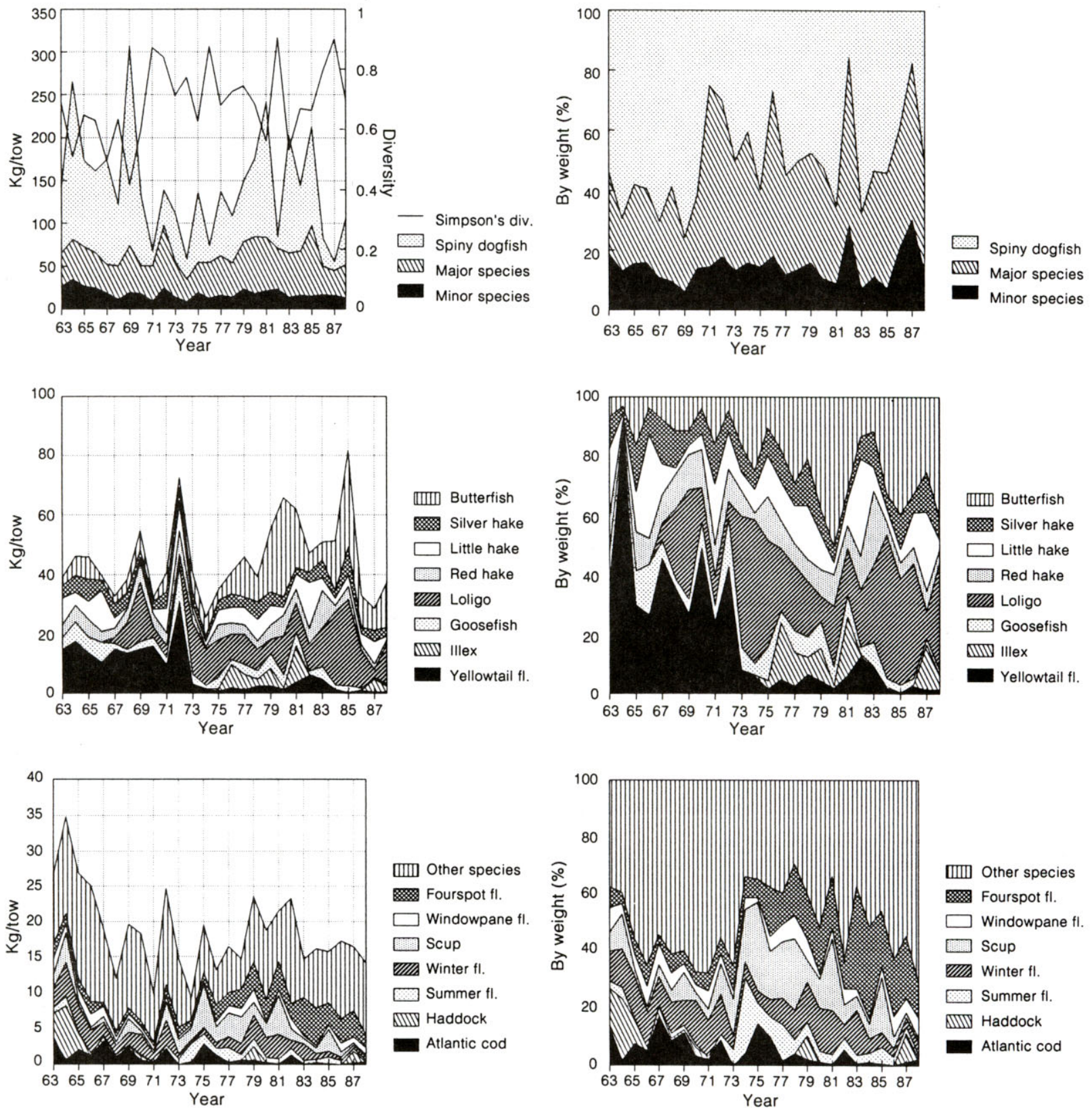

Fig. 14. Mean biomass (kg/tow), percent biomass and Simpson's diversity index, Northern Mid-Atlantic Bight survey summary region (survey strata 1-2, 5-6, 9-10), 1963-88 based on 54 species (Table 1). Totals as mean kg/ tow (left panels) and percent total mean kg/tow (right panels) are aggregated over sets of major and minor species in top panels, and disaggregated by individual species in middle and bottom panels.

1968; Gabriel and Tyler, 1980; Colvocoresses and Musick, 1984; Overholtz and Tyler, 1985; Mahon and Smith, 1989).

South of Georges Bank, persistent sharp boundaries related to fixed spatial features (such as depth contours) become less common. This may arise if boundary location is influenced by oceanographic features that shift in location from year to year, or if the system is characterized by distributions along gradients. In the former case, several oceanographic features in the Mid-Atlantic Bight shift in extent or location from year to year, including the Cold Pool (extending southward between 40-100 m isobaths), a warm water belt along the southern edge of Georges Bank, and the Shelf-Slope front (Cook, 1988). Assemblage region boundaries (including the northern edge of the Southern Mid- 

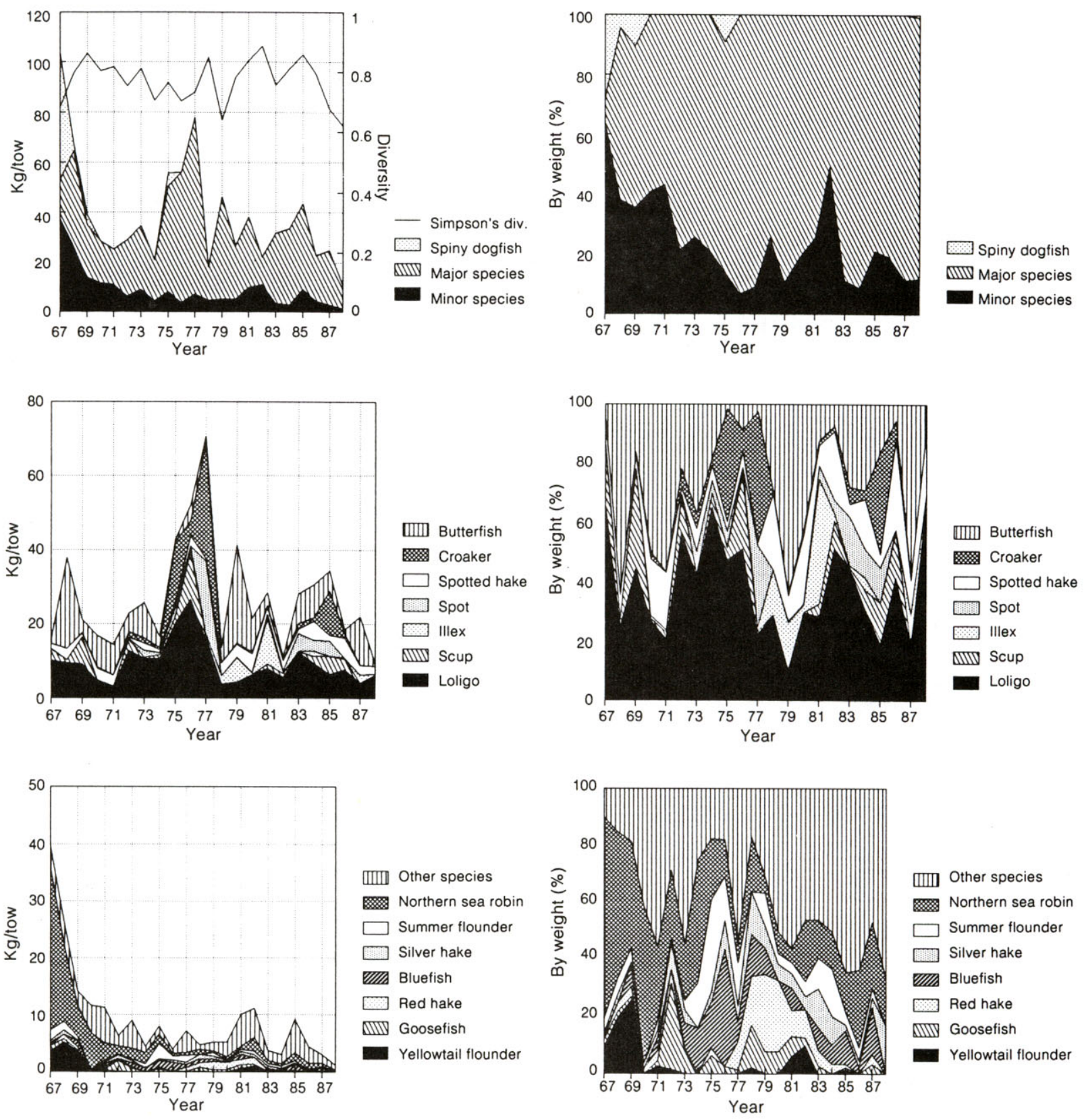

Fig. 15. Mean biomass (kg/tow), percent biomass and Simpson's diversity index, Southern Mid-Atlantic Bight survey summary region (survey strata 61-62, 65-66, 69-70, 73-74), 1967-88 based on 54 species (Table 1). Totals as mean $\mathrm{kg} / \mathrm{tow}$ (left panels) and percent total mean kg/tow (right panels) are aggregated over sets of major and minor species in top panels, and disaggregated by individual species in middle and bottom panels.

Atlantic Bight site group, the eastward extent of the Southen Mid-Atlantic Bight site group, and the shoreward extent of the Deepwater site group, respectively) occur in the vicinity of these features, although year-by-year correspondances between location of respective features and boundaries have not been made. In the latter case, the broad pattern of southwest flow along the Mid-Atlantic Bight (Cook, 1988) may imply a more open system characterized by distribution along gradients rather than a sharply bounded system with abrupt changes in distribution (Mahon and Smith, 1989).

The role of temperature and temperature-related oceanographic features in structuring assemblage distributions increases southward. Colvocoresses and Musick (1984) indicated that temperature influenced distribution of fish assemblages in the Mid-Atlantic Bight; and the observed 

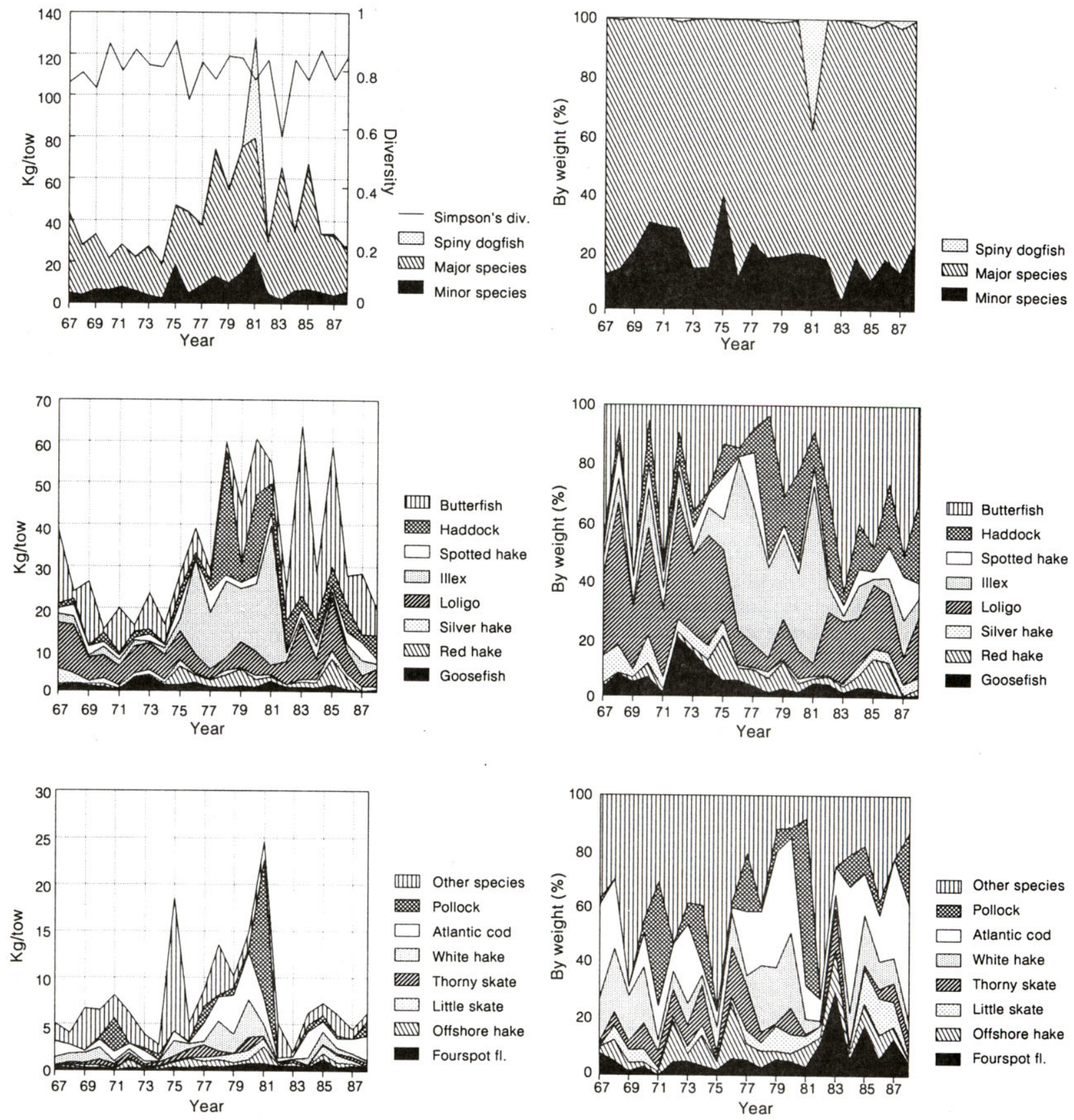

Fig. 16. Mean biomass (kg/tow), percent biomass and Simpson's diversity index, Deepwater survey summary region (survey strata 3-4, 7-8, 11-12, 14-15, 17-18,63-64, 67-68, 71-72, 75-76), 1967-88 based on 54 species (Table 1). Totals as mean kg/tow (left panels) and percent total mean $\mathrm{kg} /$ tow (right panels) are aggregated over sets of major and minor species in top panels, and disaggregated by individual species in middle and bottom panels.

northward expansion of Southern Mid-Atlantic Bight site groups during a period of warming from the late-1960s to mid-1970s is consistent with their findings. However, information on temperature preferences of component species needed to confirm effects of temperature on species distribution is presently lacking.

\section{Persistence of species associations}

The persistence of species associations observed over the 20 year study period is notable, given the history of fishery exploitation and variability in environmental regimes during the period. Persistent membership in species groups has been 
observed by other researchers for the regions of Georges Bank (Overholtz and Tyler, 1985), MidAtlantic Bight (Colvocoresses and Musick, 1984) and the Scotian Shelf (Mahon and Smith, 1989), although based on studies conducted over shorter 10-15 year periods. Stable membership in species cluster groups may reflect common ability or inability of member species to extend or change distributional ranges in response to physical or biological perturbations. Members of species groups may share a common scale of environmental perturbation to which they are resilient and which is characteristic of the distributional range of the assemblage.

\section{Regional differences in assemblage dynamics}

Although species group affiliations have persisted through time, the response of species groups to fishery perturbation varies among groups. Resident species groups (e.g. groups A, B and C which characterized northern regions with sharp persistent spatial boundaries) generally did not appear resilient under observed conditions of fishery perturbation and subsequent relaxation. In the Gulf of Maine, species group A appeared susceptible to a relatively low level of fishery perturbation in the 1960s and early-1970s that did not include a significant non-USA fishery, indicating low resistance to perturbation. Characteristic species groups on Georges Bank ( $B$ and $C$ ) declined in response to intense fishery perturbation (1964-74), but these declines were not generally reversed after the perturbation was relaxed in the following years (197581), as indexed by standardized demersal fishing effort (Mayo et al., this volume). This may be because the duration and/or degree of relaxation was insufficient to allow accumulation of recruitment as persistent stock biomass.

Not all species in an assemblage were directly affected by fishery perturbations, however. The exceptional increase in abundance of winter skate (species group C) on Georges Bank in recent years indicates that patterns in fishing mortality have had additional indirect effects and/or that additional mechanisms are significant. Winter skate may have been able to exploit increasing benthic food resources (e.g. sand lance, Ammodytes sp.) as abundance of other predators declined, or may have had a high rate of survival after being discarded.

Response of Mid-Atlantic Bight species groups to fishery perturbation cannot be established because standardized fishery effort data are unavailable. During the same period that abundance of northern resident species groups continued to decline or remained at low levels, however, some migratory or potentially temperature-responsive species groups appear to have extended their dis- tributions or increased their abundance, or both. Species in group D (long-finned squid and butterfish) and spiny dogfish in group A-B extended their distribution northward to Georges Bank during periods of warmer waters in the early- and mid-1970s. Higher levels of relative abundance of spiny dogfish in the early-1970s on Georges Bank coincide with a decline in relative abundance in the adjoining southern New England region, indicating that at least initially, the apparent increase could be attributed to a shift in distribution rather than an increase in resident abundance. Temperature, however, did not appear to be the sole feature controlling distribution of species group D on Georges Bank, since abundance levels there have not responded to yearly fluctuations in water temperatures in recent years.

Several changes in relative abundance of species group $E$ are likely to be linked with changes in temperature. Able et al. (1990) and Szedlmayer et al. (1992) indicate that for summer flounder, cold temperatures in estuaries may adversely affect yearclass strength, and relative abundance of this species showed increases during the warm periods in 1972-76. Influxes of group E species, spot, croaker and weakfish, occurred almost entirely in years of anomalously warm water in the Southern Mid-Atlantic Bight (Holzwarth and Mountain, MS 1990). This is consistent with Tyler's (1971) finding that the ratio of migratory to resident species increases southward, as within-year variability in temperature increases.

Regional differences in assemblage dynamics may be indicated by patterns of dissimilarity from cluster analyses. The southernmost groups of spatially contiguous sites generally formed at higher levels of dissimilarity than northern site groups. Likewise, groups of species with more northern centres of distribution tended to form at lower levels of dissimilarity. This indicated that patterns of cooccurrence among southern groups of species were more irregular than for northern counterparts. Trophic interactions within southern assemblages may include more stochastic, intermittent dynamics, while interactions within northern assemblages may be more continuous.

\section{Interactions between assemblages}

When relative importance of two (or more) assemblages shifts in a region, it appears unlikely that one assemblage has replaced another in the trophic structure of the community. Instead, originallydominant assemblages may remain in a region (although at lower levels after fishery perturbation) and be joined by other assemblages with more flexible distribution patterns. The result is the potential addition of trophic linkages among assemblage groups as predator-prey interactions rather 
than as competition. For example, in the Northern Mid-Atlantic Bight region, species group $\mathrm{C}$ did not appear resilient to reduced effort between 1975 and 1981, and remained at low levels of abundance since the fishery perturbation during 1963-74. At the same time, relative abundance of all members of species group D was not significantly reduced by fishing pressure between 1963 and 1974 because species may not have been as intensively targetted, and has increased since the early-1970s, concurrent with increased water temperatures. The trophic structure of the two groups differs. While members of group C prey primarily on benthic invertebrates (with sand lance as a less important fish component), significant portions of diets of all members of group D include nekton, i.e. euphausiids, cephalopods and/or fish, especially at larger predator sizes. Direct trophic linkages among group D members have been documented; e.g. all species in the group consume squid (Bowman, MS 1977; Bowman and Michaels, MS 1982; Maurer and Bowman, 1985). The intensity of predator-prey interactions between species groups $C$ and $D$ depends on preference of predators in species group D for prey from species group C.

The concept of addition rather than replacement of assemblages is also consistent with the lack of major shifts in species composition within the Gulf of Maine. Colder, deepwater habitat or benthic invertebrate food sources may be relatively unsuitable for exploitation by migratory or other potentially invasive species. The potential for significant shifts in species composition within that region may arise primarily within the piscivores (e.g. all members of group $A-B$, including large red hake, and potential predators and prey in group $M-2$ ) rather than the benthic-feeding species (group A).

The general patterns repeated over several assemblage areas/species groups are that: (1) resident species are not resilient under observed conditions of fishery perturbation and relaxation; (2) species in groups which have expanded their range and/or abundance levels in recent years are frequently underexploited and piscivorous (especially at larger body sizes). Although diversity appears to decrease southward, trophic interactions become more complex as the relative abundance of potential piscivores which can consume a variety of cooccurring species increases, and as species distribution patterns become patchier.

\section{Use of research survey data to define persistent fish assemblages}

While research vessel survey data provide standardized and reasonably accurate indices of relative abundance for commercially and ecologically important species, results must be interpreted with caution. Species compositions observed from trawl survey data will be biased toward species with greatest catchability by survey gear, so pelagic and semi-pelagic species such as Atlantic herring. Atlantic mackerel and bluefish will be underrepresented in the survey gear used in this study. As well, catchability of some species may change in years when different survey vessel and door types are used (Anon., MS 1991). In this study, however, a single trawl type was used. Cluster formation and subsequent location of assemblage region boundaries is likely to be sensitive to random station spacing associated with the survey design. Species distribution in the autumn survey may be affected by seasonal overturn in the water column, the onset of which varies in timing from year to year (Colvocoresses and Musick, 1984). Finally, although this survey time series is one of the longest available, it began well after domestic fisheries first would have had an impact on assemblage structure. For example, Merriman and Warfel (1948) suggested a shift in dominant species in a Block Island Sound assemblage from winter flounder at the outset of the flounder fishery in 1920 to little skate in 1948. They attributed the shift to fishery removals of winter flounder and subsequent replacement by little skate, based on substantial dietary overlap between the two species. Nonetheless, the survey data used in this study provide the best available indicator of relative changes in species composition and distribution for many species of ecological and commercial interest.

\section{Implications for management of fish assem- blages}

The assemblage production unit is defined as a multispecies fishery management unit composed of resident species linked trophically (Tyler et al., 1982). In this area of the Northwest Atlantic, the concept of an ambulant assemblage production unit may be appropriate, where species within such a group may be trophically linked, but their distribution as a group changes over decadal time (e.g. species group $D$ and some members of species group A-B). These units would likely also be sensitive to effects of climatic change. Changing distribution and potential changes in abundance (including local effects of immigration) also imply changing linkages with traditional resident assemblage production units. Reversibility of fishery effects on productivity of resident assemblage units will depend on the strength of the trophic linkages both within and between assemblage production units that previously may have been uncoupled or only loosely coupled.

\section{Acknowledgements}

The foresight of the initial survey designers and the enduring efforts of many other scientists of the 
Northeast Fisheries Science Center, especially those of the Resource Surveys Investigation, have led to the development of the unique and invaluable data analyzed here. I am grateful for the assistance of several individuals involved at various points in developing this paper: W. Overholtz was involved in development of initial analyses; R. Maurer assisted in development of intermediate drafts; $R$. Jenness provided technical support; and M. Fogarty encouraged perseverance.

\section{References}

ABle, K. W. , R. E. MATHeson, W. W. MORSE, M. P. FAHEY, and G. SHEPHERD. 1990. Patterns of summer flounder Paralichthys dentatus early life history in the Mid-Atlantic Bight and New Jersey estuaries. Fish. Bull. U.S., 88: 1-12.

ALMEIDA, F. P., T. R. AZAROVITZ, L. O'BRIEN, and E. W. PRITCHARD. MS 1984. The distribution of major finfish and shellfish species collected during NEFC bottom trawl surveys, 1965-1978. NMFS NEFC Lab. Ref. Doc., No. 84-21, 101 p.

ANON. MS 1991. Report of the twelfth Northeast Regional Stock Assessment Workshop (12th SAW) Spring 1991. NEFSC Lab. Ref. Doc., 91-03: 187 p.

AZAROVITZ, T. R. 1981. A brief historical review of the Woods Hole Laboratory trawl survey time series. In: Bottom trawl surveys. W. G. Doubleday and D. Rivard (eds.). Can. Spec. Publ. Fish. Aquat. Sci., 58: 62-67.

BEDDINGTON, J. R. 1984. The response of multispecies systems to perturbations. p. 209-225. In: Exploitation of Marine Communities. R. M. May (ed.). Life Sciences Research Report 32. Springer-Verlag, New York.

BOWMAN, R. E. MS 1977. Seasonal habits of demersal fish in the Northwest Atlantic-1972. NMFS, NEFC Lab. Ref. Doc., No. 77-01, 31 p.

BOWMAN, R. E., and W. L. MICHAELS. MS 1982. Food of seventeen species of Northwest Atlantic fish: part I, examination by predator length and geographic area. NMFS, NEFC Lab. Ref. Doc., No. 82-16,88 p.

BROWN, B. E., J. A. BRENNAN, M. D. GROSSLEIN, E. G. HEYERDAHL, and R. C. HENNEMUTH. 1976. The effect of fishing on the marine finfish biomass in the Northwest Atlantic from the Gulf of Maine to Cape Hatteras. ICNAF Res. Bull., 12: 49-68.

BUTMAN, B., and R. C. BEARDSLEY. 1987. Physical oceanography. p. 88-97. In: Georges Bank. R. H. Backus (ed.). The MIT Press, Cambridge, Massachusetts, $593 \mathrm{p}$.

CLIFFORD, H.T., and W. STEPHENSON. 1975. An introduction to numerical classification. Academic Press, New York. 229 p.

COLVOCORESSES, J. A., and J. A MUSICK. 1984. Species associations and community composition of Middle Atlantic Bight continental shelf demersal fishes. Fish. Bull. U.S., 82: 295-313.

COOK, S. K. 1988. Physical oceanography of the Middle Atlantic Bight. In: Characterization of the Middle Atlantic water management unit of the Northeast Re- gional Action Plan. A. L. Pacheco (ed.). NOAA Tech. Mem., NMFS-F/NEFC-56, $48 \mathrm{p}$.

DAY, D. S., and W. G. PEARCY. 1968. Species associations of benthic fishes on the continental shelf and slope off Oregon. J. Fish. Res. Board Can., 25: 26652675.

GABRIEL, W. L., and A. V. TYLER. 1980. Preliminary analysis of Pacific Coast demersal fish assemblages. Mar. Fish. Rev., (March-April): 83-88.

GROSSLEIN, M. D. 1969. Groundfish survey program of the BCF Woods Hole. Comm. Fish. Rev., 31: 22-35.

HOLZWARTH, T., and D. MOUNTAIN. MS 1990. Surface and bottom temperature distributions from the Northeast Fisheries Center spring and fall bottom trawl survey program, 1963-1987. NEFSC Lab. Ref. Doc., No. 90-03, 62 p.

ICNAF. 1955-1977. Statistical Bulletins of the International Commission for the Northwest Atlantic Fisheries. ICNAF Stat. Bull, Vol. 3-26.

LUDWIG, J.A., and J. F. REYNOLDS. 1988. Statistical ecology: a primer on methods and computing. John Wiley \& Sons, New York. $337 \mathrm{p}$.

MAHON, R., and R. W. SMITH. 1989. Demersal fish assemblages on the Scotian Shelf, Northwest Atlantic: spatial distribution and persistence. Can. J. Fish. Aquat. Sci., 46(Suppl 1): 134-152.

MAURER, R. O., and R. E. BOWMAN. 1985. Food consumption of squids (Illex illecebrosus and Loligo pealei) off the Northeastern United States. NAFO Sci. Coun. Studies, 9: 117-124.

MAYO, R. K., M. J. FOGARTY, and F. M. SERCHUK. 1992. Aggregate fish biomass and yield on Georges Bank, 1960-1987. NAFO Special Session on Changes in Biomass, Production and Species Composition of the Fish Populations in the Northwest Atlantic over the Last 30 Years and Their Possible Causes. J. Northw. Atl. Fish. Sci., this volume, p. 59-78.

MERRIMAN, D., and H. WARFEL. 1948. 5. Studies on the Marine Resources of Southern New England. VII. Analysis of a fish population Bull. Bingham. Oceanogr. Coll., 11: 131-164.

OVERHOLTZ, W. J., and A. V. TYLER. 1985. Long-term responses of the demersal fish assemblages of Georges Bank. Fish. Bull. U.S., 83: 507-520.

SHERMAN, K., and L. ALEXANDER. 1986. Variability and management of large marine ecosystems. AAAS Selected Symposium 99. Westview Press, Boulder, Colorado.

SZEDLMAYER, S. T., K. W. ABLE, and R. A. ROUNTREE. 1992. Summer flounder (Paralichthys dentatus) growth and temperature induced mortality during the first year in southern New Jersey. Copeia, 1992: 120 128.

TYLER, A. V. 1971. Periodic and resident components in communities of Atlantic fishes. J. Fish. Res. Board Can., 28: 935-946.

TYLER, A. V., W. L. GABRIEL, and W. J. OVERHOLTZ. 1982. Adaptive management based on structure of fish assemblages of Northern continental shelves. In: Multispecies approaches to fisheries management advice, M. C. Mercer (ed.). Can. Spec. Publ. Fish. Aquat. Sci., 59: 149-156. 